\title{
HUBUNGAN ASUPAN MAKANAN INDEKS GLIKEMIK TINGGI DAN AKTIVITAS FISIK DENGAN KADAR GLUKOSA DARAH PADA PASIEN DIABETES MELLITUS TIPE II RAWAT JALAN DI RSUD KARANGANYAR
}

\author{
Hernie Mayawati ${ }^{1}$, Farida Nur Isnaeni ${ }^{2}$, \\ 1,2 Program Studi Ilmu Gizi Fakultas Ilmu Kesehatan Universitas Muhammadiyah \\ Surakarta. Jl. A. Yani, Pabelan, Kartasura, Surakarta. \\ Email: ${ }^{1}$ herniemaymey9@gmail.com, ${ }^{2}$ farida.n.isnaeni@ums.ac.id
}

\begin{abstract}
ABSTRAK
Asupan makanan dengan indeks glikemik tinggi merupakan salah satu faktor yang dapat menyebabkan tingginya kadar glukosa darah. Selain itu aktivitas fisik juga dapat mengubah glukosa menjadi energi, sehingga ringan atau beratnya aktivitas fisik dapat berpengaruh pada kadar glukosa darah. Penelitian ini bertujuan untuk mengetahui hubungan asupan makanan indeks glikemik tinggi dan aktivitas fisik dengan kadar glukosa darah pada pasien diabetes mellitus tipe II rawat jalan di RSUD Karanganyar. Penelitian ini menggunakan metode observasional dengan pendekatan cross-sectional. Subjek penelitian yang digunakan adalah 52 pasien DM Tipe II yang berusia 40-65 tahun. Pengambilan sampel menggunakan accidental sampling. Data asupan makanan indeks glikemik tinggi diperoleh melalui teknik Semi Quantitatif Food Frequency Quesionnare (SQFFQ). Data aktivitas fisik menggunakan Form Recall 24 jam untuk mengetahui nilai PAL. Data kadar glukosa darah diperoleh dari catatan rekam medis RSUD Karanganyar. Uji statistik yang digunakan adalah Pearson Product Moment. Hasil penelitian menunjukkan bahwa sebagian besar responden mamiliki asupan makanan indeks glikemik tinggi yang rendah $(65,4 \%)$, aktivitas fisik yang ringan $(78,8 \%)$, dan kadar glukosa darah yang tinggi $(69,2 \%)$. Responden dengan asupan indeks glikemik tinggi yang rendah cenderung memiliki kadar glukosa darah tinggi $64,7 \%(p=0,276)$. Responden dengan aktivitas fisik ringan cenderung memiliki kadar glukosa darah tinggi $78 \% \quad(p=0,127)$. Tidak ada hubungan antara asupan makanan indeks glikemik tinggi dan aktivitas fisik dengan kadar glukosa darah pada pasien diabetes mellitus tipe II rawat jalan di RSUD Karanganyar.
\end{abstract}

Kata kunci : Aktivitas fisik, diabetes mellitus tipe II, glukosa darah, indeks glikemik

\footnotetext{
ABSTRACT

Intake of foods with high glycemic index is one of the factors that cause high blood glucose levels. In addition, physical activity can also convert glucose into energy, so light or heavy physical activity can affect blood glucose levels. This study aimed to determine the relationship between the food intake of the high glycemic index and physical activity with blood glucose levels in patients with type II
} 
diabetes outpatient in RSUD Karanganyar. This research used the observational method with cross-sectional approach. Subjects used were 52 patients with Type II DM aged 40-65 years. Sampling used was accidental. High glycemic index food intake data were obtained through Semi-Quantitative Food Frequency Questionnaire (SQFFQ) technique. Physical activity data were using 24-hour Recall Form for the PAL score. Blood glucose data obtained from medical records of RSUD Karanganyar. The statistical test used was Pearson Product Moment. The results showed that most of the respondents indicated low intake of high glycemic index food (65.4\%), light physical activity (78.8\%), and high blood glucose levels (69.2\%). Respondents with low intake of high glycemic index food were tended to have high blood glucose levels of $64.7 \%(p=0.276)$. Respondents with light physical activity were likely to have a high blood glucose levels of $78 \%$ ( $\mathrm{p}=0.127$ ). There was no association between food intake of the high glycemic index and physical activity with blood glucose level of outpatient DM in RSUD Karanganyar.

Keywords: Physical activity, diabetes mellitus type II, blood glucose, glycemic index

\section{PENDAHULUAN}

Diabetes mellitus (DM) merupakan sekelompok kelainan heterogen yang ditandai oleh kenaikan kadar glukosa dalam darah (hiperglikemia). Glukosa secara normal bersikulasi dalam jumlah tertentu dalam darah. Glukosa dibentuk di hati dari makanan yang dikonsumsi. Insulin, hormon yang diproduksi pankreas, berfungsi untuk mengendalikan kadar glukosa dalam darah dengan mengatur produksi dan penyimpanannya (Brunner dan Suddarth, 2002).

Menurut WHO (World Health Organisazation), prevalensi DM Indonesia menempati urutan keempat terbesar di dunia. Laporan dari RISKESDAS (2013) menyebutkan terjadi peningkatan prevalensi pada penderita DM di Indonesia yaitu 1,1\% pada tahun 2007 menjadi 1,5\% pada tahun 2013. Prevalensi kasus DM tipe II, pada tahun 2012 yaitu 0,55\% (Dinkes Provinsi Jawa Tengah, 2012).

Faktor-faktor yang dapat menyebabkan Diabetes Mellitus tipe II menurut American Diabetes Association (2004) yaitu genetik, usia, jenis kelamin, berat badan, stres, aktivitas fisik, pola makan. Pola makan yang kurang baik termasuk konsumsi makanan dengan indeks glikemik (IG) tinggi juga dapat memperburuk progresifitas penyakit (Ostman, 2001).

Semakin tinggi Indeks Glikemik suatu makanan maka semakin cepat dampaknya terhadap kenaikan glukosa darah. Pengaruh makanan dengan indeks glikemik tinggi adalah meningkatkan kecepatan dan menambah jumlah kadar glukosa dalam darah dengan cepat. Nilai indeks glikemik suatu makanan $\geq 70$ tergolong tinggi, sedangkan 56-69 sedang dan $\leq 55$ rendah (Ostman, 2001). Konsumsi makanan yang mengandung indeks glikemik tinggi dapat menyebabkan resistensi insulin. Selain itu merangsang penurunan sekresi insulin yang dapat mempengaruhi kerja atau fungsi dari sel b-pankreas dan menurunkan reglukosasi dari reseptor insulin. Jika pasien diabetes sering mengonsumsi makanan dengan indeks 
glikemik tinggi, maka akan berdampak pada hiperglikemik hingga komplikasi diabetes seperti katarak, gagal ginjal, serangan jantung koroner, gangren, ketoasidosis, hingga stroke (Almatsier, 2006). Hal ini menunjukkan bahwa adanya hubungan antara konsumsi makanan indeks glikemik tinggi dengan kenaikan kadar glukosa darah puasa. Berdasarkan penelitian Rizkalla dkk. (2004) pada pasien DM terjadi peningkatan kadar glukosa darah dari 9,4 menjadi 9,8 $\mathrm{mmol} / \mathrm{L}$ setelah konsumsi makanan dengan indeks glikemik tinggi. Sebaliknya terjadi penurunan kadar glukosa darah dari 10,1 menjadi 9,2 $\mathrm{mmol} / \mathrm{L}$ setelah mengkonsumsi makanan dengan indeks glikemik rendah.

Selain pola makan yang kurang baik, aktivitas fisik juga merupakan salah satu faktor yang dapat mengakibatkan resistensi insulin pada pasien DM tipe II (Soegondo, 2005). Menurut Stevenson dan lohman dalam Kriska (2007) semakin jarang melakukan aktivitas fisik maka glukosa yang dikonsumsi akan lama digunakan. Hal ini mengakibatkan peningkatan kadar glukosa dalam darah akan semakin tinggi. Penelitian dari Paramitha (2014) menunjukkan adanya hubungan yang bermakna antara aktivitas fisik dengan kadar glukosa darah pasien diabetes mellitus tipe II. Hal tersebut dikarenakan aktivitas fisik dapat mengontrol kadar glukosa darah kemudian glukosa akan diubah menjadi energi saat beraktivitas. Aktivitas fisik juga akan mengakibatkan insulin semakin meningkat sehingga kadar glukosa darah akan berkurang (Kemenkes, 2010). Berdasarkan Penelitian Listiana (2015), ditemukan juga adanya hubungan antara aktivitas fisik dengan kadar glukosa darah pada penderita diabetes mellitus tipe II pada wanita usia 45-55 tahun di kelurahan Gedawang Kecamatan Banyumanik Kota Semarang.
Penderita Diabetes Mellitus di RSUD Karanganyar pada tahun 2015 masuk dalam 10 besar penyakit rawat jalan dan menempati urutan ke- 5 . Berbagai masalah yang telah disampaikan oleh penulis menjadi alasan untuk melakukan penelitian mengenai Hubungan asupan makanan Indeks Glikemik Tinggi dan Aktivitas Fisik Dengan Kadar Glukosa Darah Pasien Rawat jalan di RSUD Karanganyar.

\section{METODE PENELITIAN}

Jenis penelitian ini adalah Observasional dengan pendekatan cross sectional di RSUD Karanganyar pada bulan Oktober 2016. Penelitian ini dinyatakan lolos etik dari Komisi Etik Penelitian Kesehatan (KEPK) Fakultas Kedokteran Universitas Muhammdiyah Surakarta dengan No:340/B.1/KEPKFKUMS/X/2016.

\section{Responden}

Pengambilan sampel menggunakan sistem accidental sampling dimana subjek kebetulan muncul pada saat pengambilan data yang sesuai dengan kriteria, diambil 52 subjek.

\section{Data asupan makanan yang memiliki indeks glikemik tinggi}

Pengambilan data asupan makanan indeks glikemik tinggi dengan wawancara langsung pada subjek menggunakan form Semi Kuantitatif $F F Q$ oleh peneliti. Data Semi Kuantitatif $F F Q$ yang didapatkan, selanjutnya dilakukan konsumsi pasien rata-rata perhari ( $\mathrm{g} / \mathrm{hari})$.

\section{Data aktivitas fisik}

Pengambilan data aktivitas fisik dengan wawancara kegiatan yang dilakukan oleh pasien mulai dari bangun tidur hingga tidur kembali, yang dilakukan selama 3x24 jam dan dihitung dengan cara melihat rata-rata nilai PAR (physical activity rate) 


\section{Kadar glukosa darah}

Kadar glukosa darah pasien yang diperiksa di laboratorium dan diambil oleh petugas pada waktu pasien kontrol dirumah sakit dengan metode GOD PAP dengan satuan $\mathrm{mg} / \mathrm{dl}$. Peneliti mengambil dari catatan rekam medik pasien.

Analisis data

Uji kenormalan data menggunakan

One Sample Kolmogorof Smirnov, kemudian uji hubungan menggunakan Pearson Product Moment.

\section{HASIL DAN PEMBAHASAN}

\section{Distribusi Karateristik Responden berdasarkan Jenis Kelamin, Usia, Pendidikan dan Pekerjaan}

Responden yang digunakan dalam penelitian ini adalah Pasien DM tipe II rawat jalan di RSUD Karanganyar yang sesuai dengan kriteria inklusi dan eksklusi yang telah ditentukan oleh peneliti. Sesuai dengan hasil penelitian diperoleh data responden penelitian meliputi distribusi berdasarkan jenis kelamin, usia, pendidikan dan pekerjaan.

Distribusi karateristik responden berdasarkan jenis kelamin, usia, pendidikan dan pekerjaan dapat dilihat pada Tabel 1.

Tabel 1. Distribusi Karakteristik Responden Berdasarkan Jenis Kelamin,

Usia, Pendidikan dan Pekerjaan

\begin{tabular}{ccc}
\hline Jenis Kelamin & Jumlah (n) & Persentase (\%) \\
\hline Laki-Laki & 16 & 30,8 \\
Perempuan & 36 & 69,2 \\
Jumlah & 52 & 100 \\
\hline Usia (tahun) & Jumlah (n) & Persentase (\%) \\
\hline $45-50$ & 7 & 13,5 \\
$51-60$ & 21 & 40,4 \\
$61-70$ & 24 & 46,2 \\
Jumlah & 52 & 100 \\
\hline Pendidikan Terakhir & Jumlah (n) & Persentase (\%) \\
\hline SD & 20 & 38,5 \\
SMP & 10 & 19,2 \\
SMA & 11 & 21,2 \\
Perguruan Tinggi & 11 & 21,2 \\
Jumlah & 52 & 100,0 \\
\hline Pekerjaan & Jumlah (n) & Persentase (\%) \\
Buruh & 3 & 5,8 \\
Wiraswasta & 9 & 17,3 \\
Tani & 6 & 11,5 \\
PNS & 6 & 11,5 \\
IRT & 18 & 34,6 \\
Tidak Bekerja & 2 & 3,8 \\
Pensiunan & 8 & 15,4 \\
Jumlah & 52 & 100,0 \\
\hline & &
\end{tabular}

Berdasarkan Tabel 1 dapat diketahui bahwa persentase perempuan penderita Diabetes Mellitus Tipe II lebih besar daripada laki-laki yaitu sebesar 69,2\%. Berdasarkan penelitian Irawan (2010) wanita lebih berisiko terkena penyakit DM karena secara fisik wanita memiliki peluang mengalami peningkatan indeks masa tubuh (IMT) yang lebih besar. Berdasarkan Tabel 2 menunjukkan bahwa persentase terbesar yaitu responden usia 61-70 tahun sebanyak 24 responden $(46,2 \%)$. Hal tersebut sesuai dengan pernyataan Jelantik dan Haryati (2014) yang menyatakan bahwa bertambahnya umur seseorang maka risiko terkena DM lebih besar. Semakin tua usia fungsi tubuh secara fisiologis menurun karena terjadi penurunan sekresi atau resistensi insulin sehingga kemampuan fungsi tubuh terhadap pengendalian glukosa darah yang tinggi kurang optimal. Berdasarkan pendidikan menunjukkan bahwa sebagian besar responden memiliki pendidikan terakhir SD (Sekolah Dasar) yaitu sebanyak 20 responden atau $38,5 \%$. Berdasarkan jenis pekerjaan sebagian besar responden (18 orang) memiliki pekerjaan IRT (Ibu Rumah Tangga). Menurut Kemenkes (2010), jenis pekerjaan dapat mempengaruhi aktivitas fisik. Aktivitas fisik dapat mengontrol glukosa darah. Semakin Berat Aktivitas fisik maka akan semakin cepat glukosa darah akan diubah menjadi energi.

\section{Distribusi Karakteristik Responden berdasarkan Aktivitas Fisik}

Distribusi karakteristik responden berdasarkan aktivitas fisik dapat dilihat pada Tabel 2.

Tabel 2. Distribusi Karakteristik Responden berdasarkan Aktivitas Fisik

\begin{tabular}{ccc}
\hline Aktivitas Fisik & Jumlah (n) & Persentase (\%) \\
\hline Ringan & 41 & 78,8 \\
Sedang & 10 & 19,2 \\
Berat & 1 & 1,9 \\
Jumlah & 52 & 100,0 \\
\hline
\end{tabular}


Berdasarkan Tabel 2 didapatkan rata-rata yaitu sebagian besar responden $(78,8 \%)$ memiliki aktivitas fisik ringan.Aktivitas fisik mempengaruhi kadar glukosa dalam darah. Ketika aktivitas tubuh tinggi, penggunaan glukosa oleh otot akan ikut meningkat. Sintesis glukosa endogen akan ditingkatkan untuk menjaga agar kadar glukosa dalam darah tetap seimbang. Pada keadaan normal, keadaan homeostasis ini dapat dicapai oleh berbagai mekanisme dari sistem hormonal, saraf, dan regulasi glukosa (Kronenberg dkk., 2008).

\section{Distribusi Karakteristik Responden berdasarkan Asupan Makanan Indeks Glikemik Tinggi}

Distribusi karakteristik responden berdasarkan asupan makanan indeks glikemik tinggi dapat dilihat pada Tabel 3 .

Tabel 3. Distribusi karakteristik responden berdasarkan asupan makanan indeks

\begin{tabular}{ccc}
\multicolumn{3}{c}{ glikemik tinggi } \\
\hline $\begin{array}{c}\text { Asupan Makanan } \\
\text { IG Tinggi }\end{array}$ & Jumlah (n) & $\begin{array}{c}\text { Persentase } \\
(\mathbf{\%})\end{array}$ \\
\hline Rendah & 34 & 65,4 \\
Tinggi & 18 & 34,6 \\
\hline Jumlah & 52 & 100,0 \\
\hline
\end{tabular}

Sebagian besar responden $(65,4 \%)$ memiliki asupan makanan IG tinggi yang rendah. Efek metabolisme berhubungan dengan tingkat penyerapan glukosa di usus kecil. Tingkat penurunan penyerapan glukosa setelah mengkonsumsi makanan sumber karbohidrat yang ber-IG rendah akan mengurangi kenaikan postprandial hormon di usus (misalnya, incretins) dan insulin. Penyerapan karbohidrat secara berkepanjangan akan mempertahankan penekanan asam lemak bebas (FFA) dan respon counterreglukosatory, sehingga pada saat yang sama konsentrasi glukosa darah rendah, begitu sebaliknya (Jenkins dkk., 2002).

\section{Distribusi Karakteristik Responden berdasarkan Kadar Glukosa Darah Puasa}

Distribusi karakteristik responden berdasarkan kadar glukosa darah puasa dapat dilihat pada Tabel 4.

Tabel 4. Distribusi karakteristik responden berdasarkan asupan makanan indeks glikemik tinggi

\begin{tabular}{ccc}
\hline $\begin{array}{c}\text { Glukosa Darah } \\
\text { Puasa }\end{array}$ & $\begin{array}{c}\text { Jumlah } \\
(\mathbf{n})\end{array}$ & $\begin{array}{c}\text { Persentase } \\
(\boldsymbol{\%})\end{array}$ \\
\hline Kurang & 12 & 23,1 \\
Normal & 4 & 7,7 \\
Tinggi & 36 & 69,2 \\
\hline Jumlah & 52 & 100,0 \\
\hline
\end{tabular}

Berdasarkan Tabel 4 sebagian besar responden di RSUD Karanganyar yang menderita DM tipe II memiliki kadar glukosa darah puasa tinggi sebesar 69,2 $\%$, normal $7,7 \%$ dan kurang $23,1 \%$.

\section{Hubungan Aktivitas Fisik dengan Kadar Glukosa Darah \\ Hasil uji hubungan Aktivitas Fisik dengan Kadar Glukosa Darah dapat dilihat pada Tabel 5.}

Tabel 5. Hubungan Aktivitas Fisik dengan Kadar Glukosa Darah

\begin{tabular}{|c|c|c|c|c|c|c|c|c|c|}
\hline \multirow{3}{*}{$\begin{array}{c}\text { Aktivitas } \\
\text { Fisik }\end{array}$} & \multicolumn{6}{|c|}{ Kadar Glukosa Darah Puasa } & \multirow{2}{*}{\multicolumn{2}{|c|}{ Total }} & \multirow{3}{*}{ Nilai p } \\
\hline & \multicolumn{2}{|c|}{ Kurang } & \multicolumn{2}{|c|}{ Normal } & \multicolumn{2}{|c|}{ Tinggi } & & & \\
\hline & $\mathbf{n}$ & $\%$ & $\mathbf{n}$ & $\%$ & n & $\%$ & n & $\%$ & \\
\hline Ringan & 6 & 14,6 & 3 & 7,3 & 32 & 78,0 & 41 & 100 & \\
\hline Sedang & 5 & 50,0 & 1 & 10,0 & 4 & 40,0 & 10 & 100 & $0,127 *$ \\
\hline Berat & 1 & 100 & 0 & 0 & 0 & 0 & 1 & 100 & \\
\hline Jumlah & 12 & 23,1 & 4 & 7,7 & 36 & 69,2 & 52 & 100 & \\
\hline
\end{tabular}

Berdasarkan Tabel 5, Hasil analisis statistik uji hubungan dengan menggunakan uji Pearson Product
Moment pada uji hubungan aktivitas fisik dengan kadar glukosa darah didapatkan nilai $\mathrm{p}=0,127$. Berdasarkan data hasil uji 
diatas dapat diketahui bahwa nilai $\mathrm{p}$ value $\geq 0,05$, maka Ho diterima yang berarti tidak ada hubungan antara aktivitas fisik dengan kadar glukosa darah. Hasil penelitian ini sesuai dengan penelitian yang dilakukan oleh Hariyanto (2013) bahwa tidak ada hubungan antara aktivitas fisik dan kadar glukosa darah puasa.

Selain itu, walaupun secara statistik tidak ada hubungan antara aktivitas fisik dan kadar glukosa darah namun pada Tabel 5 dapat dilihat bahwa terdapat kecenderungan responden yang memiliki aktivitas fisik yang ringan memiliki kadar glukosa darah puasa yang tinggi dan sebaliknya responden yang memiliki aktivitas fisik yang berat memiliki kadar glukosa darah puasa yang berat.

Penelitian ini tidak sesuai dengan penelitian Paramitha (2014) yang menunjukkan adanya hubungan antara aktivitas fisik dan kadar glukosa darah. Saat seseorang melakukan aktivitas fisik maka akan menurunkan resistensi insulin dan akan menurunkan kadar glukosa dalam darah. Masalah yang terjadi dalam DM tipe II yaitu terjadinya resistensi insulin yang dapat menyebabkan glukosa tidak dapat masuk kedalam sel (Ilyas, 2011).

Berdasarkan hasil penelitian menunjukkan bahwa 32 responden $(78,0 \%)$ dengan aktivitas fisik yang ringan memiliki kadar glukosa darah puasa yang tinggi. Sedangkan 3 responden $(7,3 \%)$ dengan aktivitas fisik yang ringan memiliki kadar glukosa darah puasa normal dan 6 responden $(14,6 \%)$ dengan aktivitas fisik ringan memiliki kadar glukosa darah kurang.

Responden dengan aktivitas fisik sedang sebagian besar memiliki kadar glukosa darah yang kurang yaitu 5 responden $(50 \%), 4$ responden $(40 \%)$ dengan kadar glukosa darah tinggi dan hanya 1 responden $(10 \%)$ dengan aktivitas fisik sedang yang memiliki kadar glukosa darah puasa yang tinggi. Sedangkan hanya 1 responden $(100 \%)$ dengan aktivitas fisik yang berat dan memiliki kadar glukosa darah yang ringan .

Pada orang yang jarang melakukan aktifitas fisik, maka zat makanan yang masuk ke dalam tubuh tidak dibakar namun ditimbun didalam tubuh sebagai gula dan lemak. Jika insulin tidak mencukupi mengubah glukosa menjadi energi maka akan menyebabkan meningkatkannya kadar glukosa dalam darah (Perkeni, 2011). Olahraga dapat mencegah peningkatan kadar glukosa darah disebabkan karena bertambahnya sensitivitas insulin yang dapat dicapai dengan pengurangan berat badan melalui bertambahnya aktivitas fisik (WHO, 1994).

\section{Hubungan Asupan Makanan Indeks Glikemik Tinggi dengan Kadar Glukosa Darah}

Hasil uji hubungan asupan makanan indeks glikemik tinggi dengan kadar glukosa darah dapat dilihat pada Tabel 6 .

Tabel 6. Hubungan Asupan Makanan Indeks glikemik Tingi dengan Kadar Glukosa Darah

\begin{tabular}{|c|c|c|c|c|c|c|c|c|c|}
\hline \multirow{3}{*}{$\begin{array}{l}\text { Asupan } \\
\text { Makanan } \\
\text { IG Tinggi }\end{array}$} & \multicolumn{6}{|c|}{ Kadar Glukosa Darah Puasa } & \multirow{2}{*}{\multicolumn{2}{|c|}{ Total }} & \multirow{3}{*}{ Nilai p } \\
\hline & \multicolumn{2}{|c|}{ Kurang } & \multicolumn{2}{|c|}{ Normal } & \multicolumn{2}{|c|}{ Tinggi } & & & \\
\hline & n & $\%$ & $\mathbf{n}$ & $\%$ & n & $\%$ & $\mathbf{n}$ & $\%$ & \\
\hline Rendah & 9 & 26,5 & 3 & 8,8 & 22 & 64,7 & 34 & 100 & $0,276^{*}$ \\
\hline Tinggi & 3 & 16,7 & 1 & 5,6 & 14 & 77,8 & 18 & 100 & \\
\hline Jumlah & 12 & 23,1 & 4 & 7,7 & 36 & 69,2 & 52 & 100 & \\
\hline
\end{tabular}

Berdasarkan Jenny Miller dalam Waspadji (2003), indeks glikemik dibagi menjadi 3 kategori yaitu rendah $\leq 55$, sedang 56-69 dan tinggi $\geq 70$. Hasil 
analisis statistik uji hubungan dengan menggunakan uji Pearson Product Moment pada uji hubungan asupan makanan indeks glikemik tinggi dan kadar glukosa darah adalah nilai $\mathrm{p}=0,276$, maka Ho diterima sehingga tidak ada hubungan antara asupan makanan indeks glikemik tinggi dengan kadar glukosa darah. Pernyataan tersebut sesuai dengan penelitian yang dilakukan oleh Wiardani (2012) bahwa tidak ada hubungan yang signifikan antara Indeks Glikemik dengan pengendalian gula darah.

Menurut Rimbawan dan Siagian (2004) banyak pangan berkarbohidrat seperti beras, kentang dan roti yang dapat dicerna dan diserap sangat cepat sehingga dapat meningkatkan kadar glukosa darah. Karbohidrat dalam pangan yang dapat dipecah dengan cepat selama proses percernaan memiliki indeks glikemik tinggi, jika karbohidrat dalam pangan dipecah secara lambat sehingga pelepasan glukosa ke dalam darah berjalan lambat memiliki indeks glikemik rendah.

Pada penelitian ini tidak terdapat hubungan antara asupan makanan IG tinggi dengan kadar glukosa darah. Karena selain asupan makanan dengan IG tinggi faktor lain seperti asupan karbohidrat juga mempengaruhi kadar glukosa darah. Faktor lain yang dapat mempengaruhi kenaikan kadar glukosa darah yaitu pola makan, selain itu lamanya menderita DM juga dapat mempengaruhi kontrol glukosa darah (Sustrani, 2006).

Hasil penelitian menunjukkan bahwa sebagian besar responden dengan asupan makanan dengan IG tinggi rendah memiliki kadar glukosa darah yang tinggi yaitu sebanyak 22 reponden $(64,7 \%)$, dibandingkan reponden dengan asupan makanan IG tinggi yang memiliki kadar glukosa darah normal 3 responden $(8,8 \%)$ dan 9 responden $(26,5 \%)$ dengan asupan glukosa darah yang kurang.

Sedangkan responden dengan asupan makanan dengan IG tinggi yang tinggi sebanyak 14 responden $(77,8 \%)$ memiliki kadar glukosa darah yang tinggi, 1 responden (5.6\%) dengan asupan glukosa darah yang normal dan 12 responden $(23,1 \%)$ dengan glukosa darah yang kurang.

\section{KESIMPULAN}

1. Karakteristik responden pada penelitian ini sebagian besar adalah perempuan (69,2\%), dengan rentang usia 61-70 tahun (46,2\%). Responden sebagian besar berpendidikan SD (38,5\%). Pekerjaan sebagian besar dari reponden yaitu Ibu Rumah Tangga (34,6\%).

2. Aktivitas fisik responden dalam penelitian ini sebagian besar dalam kategori ringan nilai PAL 1,4 - 1,69 $(78,8 \%)$

3. Asupan makanan indeks glikemik tinggi dalam penelitian ini sebagian besar dalam kategori rendah $(65,4 \%)$

4. Kadar glukosa darah puasa responden dalam penelitian ini sebagian besar dalam kategori tinggi yaitu $\geq 126 \mathrm{mg} / \mathrm{dl}(69,2 \%)$

5. Tidak ada hubungan aktivitas fisik dengan kadar glukosa darah pada pasien DM tipe II rawat jalan di RSUD Karanganyar dengan nilai $\mathrm{p}=0,127$

6. Tidak ada hubungan asupan makanan indeks glikemik tinggi dengan kadar glukosa darah pada pasien DM tipe II rawat jalan di RSUD Karanganyar dengan nilai $\mathrm{p}=0,276$

\section{DAFTAR PUSTAKA}

Almatsier, S., 2006, Prinsip Dasar Ilmu Gizi, edisi ke -6, Gramedia Pustaka utama, Jakarta. 
American Diabetes Association (ADA)., 2004, Diagnosis and Classification of DM, Diabetes Care, vol 27.

Badan Penelitian dan Pengembangan Kesehatan., 2013, Riset Kesehatan Dasar (RISKESDAS) 2013, Kementrian Kesehatan Republik Indonesia.

Brunner dan Suddarth., 2002, Buku Ajar Keperawatan Medikal Bedah, Edisi 8, EGC, Jakarta.

Dinkes Provinsi Jawa Tengah., 2012, Buku Profil Kesehatan, Dinkes Provinsi Jawa Tengah, Semarang.

Hariyanto, F., 2013, Hubungan Aktivitas Fisik dengan Kadar Gula Darah Puasa pada Pasien Diabetes Mellitus Tipe 2 di Rumah Sakit Umum Daerah Kota Cilegon Tahun 2013, Skripsi, Program Studi Pendidikan Dokter Fakultas Kedokteran dan Ilmu Kesehatan Universitas Islam Negeri Syarif Hidayatullah Jakarta, Jakarta.

Jelantik, I.M.G dan Haryati, E., 2014, Hubungan Faktor Resiko, Jenis Kelamin, Kegemukan dan Hipertensi dengan Kejadian Diabetes Mellitus Tipe II di Wilayah Kerja Puskesmas Mataram, Media Bina Ilmiah Vol 8: No1.

Ilyas, E. I., 2011, Olahraga bagi Diabetesi dalam: Soegondo, S., Soewondo, P., Subekti, I., Editor. Penatalaksanaan Diabetes Mellitus Terpadu bagi dokter maupun edukator diabetes, Fakultas Kedokteran Universitas Indonesia, Jakarta.

Irawan, D., 2010, Prevalensi dan Faktor Risiko Kejadian Diabetes Mellitus Tipe 2 di Daerah Urban Indonesia (Analisa Data Sekunder Riskesdas 2007), Tesis, Universitas Indonesia, Jakarta.

Jenkins DJ, Kendall CW, Augustin LS., 2002, Glycemic index: overweightview of implications in health and disease, Am J Clin Nutr 76, 266S-273S .

Kementrian Kesehatan Indonesia., 2010, Profil Kesehatan Indonesia Tahun 2009. Kementrian Kesehatan RI, Jakarta.

Kriska, S., 2007, Cara Mudah Mencegah Dan Mengatasi Diabetes Mellitus, Aulia Publising, Yogyakarta.

Kronenberg, H., Larsen, P.R., Polonsky, K., Melmed, S., 2008, Williams Textbook of Endocrinology, Saunders Elservier Publishing; 11: 1563-80.

Listiana, N., Mulyasari, I., Paundrianagari, MD., 2015, Hubungan asupan karbohidrat sederhana dan aktivitas fisik dengan kadar glukosa darah pada penderita diabetes mellitus tipe 2 wanita usia 45-55 tahun di kelurahan Gedawang kecamatan Banyumanik kota Semarang, Jurnal Gizi dan Kesehatan volume 7 no 13. 
Ostman, E.M., 2001, Regular of produk "Inconsistency between glycemic and insulinemic responses", American Journal of Clinical Nutrition 74 (1): pp. 96100. PMID11451723.

Paramitha, G.M., 2014, Hubungan Aktivitas fisik dengan kadar gula darah pada pasien Diabetes Mellitus Tipe II di RSUD Karanganyar, Skripsi, Fakultas Kedokteran, Universitas Muhammadiyah Surakarta, Surakarta.

Perkeni., 2011, Konsensus Pengelolaan DM di Indonesia, PERKENI, Jakarta.

Rimbawan dan Siagian, A., 2004, Indeks Glikemik Pangan, Penebar Swadaya, Jakarta.

Rizkalla SW, Laika T, Laromiguiere M, Huet D, Boillot J, Rigoir A, Slama G., 2004, Improved plasma glucose control, whole body glucose utilization and lipid profile on a low glycemic index diet in type 2 diabetic men: A randomizedcontrolled trial, Diabetes Care 2004; 27:1866-72.

Soegondo., 2005, Diabetes Mellitus Penalataksanaan Terpadu, Balai Penerbitan FKUI, Jakarta.

Sustrani, L., Alam, S., Hadibroto, L., 2006, Diabetes, PT Gramedia Pustaka Utama, Jakarta.

Waspadji, S., Suyono., Sukardji, K., Moenarko, R., 2003, Indeks Glikemik Berbagai Makanan Indonesia, Balai Penerbitan FKUI, Jakarta.

Wiardani, N.K, Ni Nyoman S, Yusi S., 2012, Indeks Glikemik Menu Makanan Rumah Sakit Dan Pengendalian Glukosa Darah Pada Pasien Diabetes Mellitus Rawat Inap Di RSUP Sanglah Denpasar, Jurnal Skala Husada, Volume 9 Nomor 1 April 2012 : 44-50.

WHO., 1994, Prevention of Diabetes Mellitus kchnical Report Series. Geneva. 
JURNAL KESEHATAN, ISSN 1979-7621, Vol. 10, No. 1. Juni 2017 